\title{
STEREOTYP I AUTOSTEREOTYP POLAKA W WYPOWIEDZIACH UCZESTNIKÓW PROGRAMU TELEWIZYJNEGO „EUROPA DA SIĘ LUBIĆ"
}

\author{
Stereotype and Autostereotype of a Pole in the Statements of the Participants \\ of the Television Programme "Europe can be liked"
}

Keywords: stereotype, autostereotype, Pole, TV programme, "Europe can be liked"

Contact: Uniwersytet Humanistyczno-Przyrodniczy im. Jana Długosza w Czestochowie; boguslaw.bogusz@ujd.edu.pl

\section{Wstęp}

Artykuł stara się przedstawić zagadnienie stereotypu narodowego Polaka oraz to jak widzi siebie stereotypowo Polak, mówiąc do przedstawicieli innych narodów. Posłużenie się materiałem programu telewizyjnego „Europa da się lubić” ma pokazać bardziej współczesny obraz stereotypu niż dotychczas przedstawiane, które czerpią przykłady często ze źródeł pisanych, bardziej tradycyjnych. Do analizy zostało wybrane łącznie pięć odcinków programu telewizyjnego z pierwszej i ostatniej edycji.

Ze względu na obszerność tematu zostało pominięte zagadnienie języka używanego w mediach, ponieważ wykracza to poza przyjętą perspektywę oraz ramy artykułu.

\section{Podstawowe pojęcia związane ze stereotypem}

Etymologię pojęcia „stereotypu” Jerzy Bartmiński wywodzi z j. greckiego (stereós 'twardy'), a znaczenie tego słowa w języku drukarzy odnosiło się do kopii pierwotnej formy drukarskiej używanej do druku wypukłego (Bartmiński, Panasiuk 2014: 372). Piotr Przybysz (2007: 97) natomiast wskazuje na nieco inny, rozszerzony źródłosłów tego terminu (stereós - 'stanowiący bryłę' oraz týpos - 'odcisk', 'ślad'). Choć nieznacznie etymologia różni się $\mathrm{w}$ tych dwóch przykładach, to jednak wyraźnie wskazuje ona na pewnego rodzaju odporność, trwałość stereotypu, o czym jeszcze będzie wspomniane w dalszej części artykułu. 
Najczęściej podawany przykład pierwszej ze znanych definicji stereotypu autorstwa Waltera Lippmanna (Lippmann 1922: 67) przedstawia to pojęcie jako mniej lub bardziej spójny obraz świata, do którego dostosowały się nasze nawyki, upodobania, zdolności, przyzwyczajenia i nadzieje (,They are an ordered, more or less consistent picture of the world, to which our habits, our tastes, our capacities, our comforts and our hopes have adjusted themselves").

Na językowy charakter stereotypu - gdyż dostęp do niego możliwy jest poprzez znaczenia słów - zwracają uwagę między innymi Jerzy Bartmiński i Jolanta Panasiuk (Bartmiński, Panasiuk 2014: 373) oraz Uta M. Quatshoff, która twierdzi, że stereotyp jest „werbalnym wyrazem przekonania skierowanego na grupy społeczne lub na jednostkę jako członka tej grupy. Ma formę logiczną sądu, który w sposób nie zweryfikowany, z tendencją do wartościowania emocjonalnego przypisuje pewnej klasie osób określone właściwości lub sposoby zachowań, ewentualnie odmawia jej jakichś cech. Językoznawczo opisywany jest jako zdanie" (Quatshoff 1998: 13). Ta definicja, z racji językoznawczego charakteru analiz materiału badawczego, będzie podstawą opisu autostereotypu i stereotypu w tym artykule.

Warto jeszcze przytoczyć nieco inne, interdyscyplinarne spojrzenie na stereotypy, w którym wskazywane są takie ich właściwości jak: niepojęciowy charakter, lecz odzwierciedlenie zjawisk społecznych; wywodzenie się nie z bezpośredniego doświadczenia jednostek, lecz $\mathrm{z}$ tradycji, przekazu i zapośredniczenia; mocne zakotwiczenie w świadomości zbiorowej uodparnia ich na doświadczenia, które nie są zgodne z wcześniej ustalonymi wyobrażeniami (Berting, Villian-Gandossi 1995: 14). Ponadto stereotypy uważane są - nie tylko w podejściu interdyscyplinarnym - za czynnik scalający społeczeństwo; są sądami (pozytywnymi lub negatywnymi) opartymi na przekonaniu; posiadają społeczną genezę i są przekazywane przez środowisko jednostce bez względu na jej osobiste doświadczenia jako wyraz opinii publicznej; są nacechowane (pozytywnie lub negatywnie), choć jawią się jako prawdziwe, to tylko częściowo zgodne są z faktami lub nawet zupełnie sprzeczne; przez długi czas pozostają niezmienne ze względu na dużą niezależność od faktycznych doświadczeń ludzi.

Wymienione wyżej cechy umożliwiają stereotypom pełnienie funkcji społecznej, obronnej w stosunku do przyjętych przez społeczeństwo lub grupę wartości i sądów. Z faktu, iż stereotypy posiadają właściwości kognitywne, łączące się z czynnikami emocjonalnymi, wynika aspekt pragmatyczny, a obejmuje on cztery funkcje: integrująca, defensywna, ideologiczno-kreatywna oraz polityczna (Berting, VillianGandossi 1995: 15). 
Szczególną rolę w całym zbiorze stereotypów odgrywają etnostereotypy, czyli obrazy wspólnot narodowych kreślone przez obserwatorów z zewnątrz jak i same nacje, które $\mathrm{w}$ ten sposób również określają swoją tożsamość. Tworzenie etnicznego autostereotypu (najczęściej pozytywnego) związane było zawsze z budowaniem dumy, poczucia własnej siły i wiązało się również z powstawaniem stereotypów „innych”, „drugich” (Krzemiński 2015: 33).

\section{Wlasny wizerunek Polaka (autostereotyp)}

W obszernym ujęciu historycznym, na podstawie zapisów pamiętnikarskich, cechy autostereotypu Polaków przedstawiła Aleksandra Niewiara (2009), która wydzieliła siedem aspektów (psychiczny i psychospołeczny, fizyczny, kulturowy, bytowy, ekonomiczny, religijny, ideologiczny) i przyporządkowała im konkretne cechy. Są to składniki autostereotypu z okresu od XVI do XX w., przy czym trzeba zaznaczyć, iż tak długi przedział czasu w niektórych przypadkach jest zasadny ze względu na dość wolną ewolucję stereotypów.

Nie wchodząc jednak w szczegóły tego opracowania, trzeba przywołać wymienione tam stereotypowe właściwości polskiego narodu występujące w najczęstszym aspekcie - psychicznym oraz psychospołecznym, jakie zostały utrwalone: (1) odważny, (2) waleczny, (3) skłonny do bijatyk, (4) kłótliwy, skłonny do sporów i waśni, (5) nieposłuszny, (6) zazdrosny, zawistny, (7) honorowy, (8) dumny/pyszny, (9) szlachetny, wspaniałomyślny, (10) uczciwy, (11) szczery, otwarty, (12) skromny, (13) prosty, (14) łagodny, (15) dobry, dobroduszny, (16) gościnny, (17) mądry i (18) głupi, (19) lekkomyślny, nietrwały, (20) ognisty, pobudliwy, (21) pełen fantazji, ducha, wesoły, skłonny do fanfaronady i głośnych przechwałek, (22) niesolidny (Niewiara 2009: 217-220).

Autocharakterystykę Polaka przedstawiają również J. Bartmiński i J. Panasiuk (Bartmiński, Panasiuk 2014: 388), wskazując na trzy prymarnie pojawiające się cechy: patriotyzm, odwagę i gościnność oraz w dalszej kolejności: honor, dumę, przywiązanie do wolności i romantyzm. Autorzy jednak obok pozytywnych cechy tego autostereotypu podają również i negatywne: pijak i handlarz oraz jednocześnie pracowity lub leniwy; zaznaczają także kontrast autostereotypu Polaka z jego zagranicznym heterostereotypem, który jest negatywny (pijany, brudny, niegospodarny, patetyczny, nacjonalistyczny, niegospodarny, katolik, obłudny, buntowniczy).

Realizacja autostereotypu Polaka w programie telewizyjnym pt. „Europa da się lubić" najczęściej pojawia się $\mathrm{w}$ wypowiedziach prowadzącej program Moniki Richardson (w ostatniej edycji programu - Moniki Zamachowskiej), zaproszonych 
gości programu oraz np. w anegdotach opowiadanych przez obcokrajowców, w których Polacy definiują (zazwyczaj częściowo) siebie samych.

Zawarte w przykładach skróty, oznaczające nazwy odcinków programu oraz uczestników i gości, zostały rozwiązane na końcu artykułu.

Na autostereotyp Polaka składają się takie elementy jak:

- umiejętność dobrej zabawy w domowych warunkach, na tzw. domówce:

M. Z.: Czyli nie tańczycie na domówkach? (Ba)

M. Z.: No wiesz co? Niszczysz nasze wyobrażenie o wspaniałej, zabawowej roztańczonej Hiszpanii. (Ba)

Tutaj występuje nieco ukryty autostereotyp, który pokazuje się dopiero w zestawieniu z krajami południa Europy, które Polacy uważają za bardzo lubiące zabawę w każdej postaci. Gdy okazuje się, że kraje takie jak Włochy, Francja czy Hiszpania nie mają w swoich zwyczajach organizowania takich domówek jak w Polsce, to wówczas tworzone jest wyobrażenie o Polakach jako tych, którzy bawią się lepiej niż te stereotypowo najbardziej zabawowe nacje.

R. L.: W takiej kontrze do was, bo my Polacy, jednak umiemy się bawić. (Ba)

Ten przykład pokazuje jasno wcześniejszy wniosek - Polacy bawią się lepiej na domówkach niż „Południowcy” z Europy.

- ułańska fantazja:

M. R.: Polska z iście ułańska fantazja wkracza do Unii Europejskiej, a my $z$ równie ułańska fantazja rozpoczynamy program pod tytulem „Europa da się lubić”. (Hu)

Ten element, obecny dodatkowo $\mathrm{w}$ polskiej frazeologii i tak $\mathrm{w}$ podanym przykładzie wyrażony, charakteryzuje Polaka jako człowieka, którego stać na zabawę dużo bardziej intensywną, odważną, niestandardową niż innych. 
- snobizm, z odcieniem autoironii:

M. Z.: Stuchaj, u nas nawet jest taka tradycja w rodzinie. I nie myśl sobie, żeby było taniej, ja byle czego nie kupuję. Prawda? (śmiech) (Ba)

W tej wypowiedzi pojawia się autoironia jako replika na wcześniejszy przykład snobistycznych zachowań Polaków opisywanych przez Francuza.

M. Z.: (o ściąganiu butów przez gości przychodzących na imprezę w Polsce) Ale wiesz, że tego już prawie nie ma. Już prawie tego nie ma $w$ Polsce. Już się nie ściaga butów. (Ba)

- przesądność Polaków:

A. H.: Tak samo, nie wolno na scenie, nie wolno. (o gwizdaniu) (Wr)

Tutaj przesądność pojawia się nawet wśród zasłużonych ludzi kultury takich jak Adam Hanuszkiewicz, co można interpretować jako głęboko zakorzenioną cechę narodową (stereotypową), która nie jest kojarzona tylko z mało wykształconą częścią społeczeństwa, najbardziej podatną na myślenie irracjonalne.

- poczucie humoru:

M. R.: Ale wiesz, co mówiq. Mówiqu, że tak naprawdę to poczucie humoru potrafi być czymś takim, co taczy narody, nawet jeśli się tego języka nie zna w stopniu idealnym. Tylko tutaj tego nie widze, kochana, no bo to jak to polskie poczucie humoru i niemieckie ... (Hu)

W tym przykładzie pokazany jest stereotypowy brak poczucia humoru u Niemca, a zestawiony z nim Polak wypada dużo lepiej, jako ten, którego cechuje bardzo wesołe usposobienie.

- oszczędzanie, aby zrobić wystawne rodzinne spotkanie (wigilijne):

M. K.: No oczywiście, że siadamy. Moniko, my sie(sic!) nawet caly rok oszczędzamy, żeby móc świętować gwiazdkę.

M. R.: To prawie tak jak $w$ Polsce. (Św) 
- zachowywanie tradycji świątecznych:

C. M.: (...) a mianowicie, wielu młodych Hiszpanów dzisiaj wychodzi yy na tak zwane imprezy wigilijne, co myślę, że jest zupetnie niezgodne z naszym polskim wyobrażeniem wigilii. (Św)

M. R.: Kolejna bardzo ważna sprawa dla nas, ubieranie choinki. Nam Polakom zawsze się wydawato, że to taki pradawny obyczaj. Teraz już wiemy, że to nieprawda. (Św)

- emigracja, podróżowanie po świecie:

J. C.: Marylo, napisatem dla ciebie kiedyś piosenkę „Kolęda dla rozsianych po świecie", a dzisiaj zobacz, ci niedawno rozsiani po świecie siedza przy polskim stole i to jest piękne. Wesolych świat!

W tym przykładzie wyraźnie pokazuje się przekonanie, że część Polaków wyjechała poza granice ojczyzny i nie będzie mogła razem z najbliższą rodziną (ale też i może z tą rodziną najszerzej rozumianą, czyli całym narodem) spędzać najbardziej rodzinnych świąt, czyli Bożego Narodzenia.

- Polak patriota-bimbrownik (autoironia):

J. B.: To jest przepis na bimber. No tak, kilogram cukru, proszę ciebie, cztery litry wody i dziesięć deko drożdży. Tysiąc czterysta dziesięć.

Cecha ta została dopowiedziana jako replika na wcześniejszą anegdotę, w której pojawiła się data bitwy pod Grunwaldem - 1410 - i została poddana autoironicznej reinterpretacji, z której wyłonił się taki element autocharakterystyki, nawiązujący zapewne do stereotypu pijaka, który często pojawia się w krajach Europy Zachodniej.

\section{Stereotyp Polaka (heterostereotyp)}

Stereotypowy Polak określany jest następująco przez Europejczyków, uczestników programu telewizyjnego:

- Polak-patriota zna najważniejsze daty historii kraju: tutaj ważna jest dokładna data bitwy pod Grunwaldem:

K. A.: Iii do tego tatuażu jest yyy jedna pewna historia. Wszedtem do faceta, u którego yyy ... chciałem zrobić ten tatuaż w ogóle ii jakoś wahat 
sie (sic!) powoli, bo on on musiat zrobić to komuś, który nie jest Polakiem, prawda, on byt tak ... (...)

K. A.: Jak ja opowiem (sic!) dobrze na te trzy pytanie(sic!), to zrobi mi ten tatuaż. Ja powiedziałem: „,Dobrze, to wal!”. I on tak yyy: w której bitwie yyy dano królowi polskiemu dwa miecze? (...) A w którym roku? (...) A data tej bitwy? (Hu)

Występująca w anegdocie historia może być również rozpatrywana z perspektywy Polaka (autostereotyp), który takie wymagania stawia obcokrajowcowi, chcącemu wytatuować sobie polskie godło na ramieniu. W tym przypadku jednak opowiastka została potraktowana z perspektywy Anglika, który ją przedstawia i tym samym w głównej mierze to on określa Polaków.

- Polacy potrafią się bawić w domach, na tzw. domówkach w przeciwieństwie do innych krajów europejskich, szczególnie tych uważanych w Polsce za skłonne do rozrywki (Hiszpania, Włochy):

L. D.: U nas ja nie wyobrażam sobie na przyktad czterdzieści osoby w moim domu będa mieć zniscyć (sic!) dom jak końcy (sic!) się dom. Bo $u$ was to jest jak mały klub. (Ba)

L. D.: Ale u nas się nie tańcy (sic!). (Ba)

F. C.: W Italii nie zabawimy tak we $w$ domu. Ja bardzo szanuje wasze kultura, dlaczego w domu dacie rade zabawić. Y... my nie. My wszyszko (sic!) na baru, na dworze. Na przyklad na baru, na ristorante, na diskoteka, podobne na Hiszpania (sic!). (Ba)

- pycha, przechwalanie się:

D. G.: Tak, troszeczkę mam wrażenie, że jak ktoś przychodzi z winami czy jakiś (sic!) mocnymi trunkami, przepraszam, że może tak używam takie stowo: „podpisywać (sic!) się”, że „patrz, mam, mam najlepsze butelke, patrz, butelkę, która przyniostem, to jest ta (sic!), możemy ja pić”.

Takie... To nie jest tak, że zostawimy butelkę i idziemy. Ktoś tam... żeśmy to pokazać. (Ba)

- przesądność:

K. A.: A ja tu mam ten problem w Polsce, że jak syreny (sic!) wyje, to Polacy nie znaja tego przesadu, więc szukam tego matego chtopaka ... (Wr) 
K. A.: Dla mnie to oczywiście w Anglii nie mamy mnóstwo, ale wydaje mi sie (sic!) że tak jak w Polsce, pęknięty (sic!) lustro ... yyy ... (Wr)

W wybranych przypadkach u Polaków ta przesądność jest większa i częściej obecna niż w niektórych krajach skłonność do ulegania wróżbom:

S. M.: Stuchaj, y... w Niemczech ominętem (sic!) wszystkie wróżby, nigdy nie bytem u wróżki, a w Polsce co (sic!) jest trochę trudniej, bo sa Andrzejki, nie, $i$ wtedy każdy normalny, nawet racjonalny Polak jakoś tam wróży sobie. (Wr)

- sport: Polacy mają obecnie słabą drużynę piłki nożnej, ale:

K. A.: Bo Polacy wiedza, że nie mają i tak szansy. (Sp)

S. M.: Kevin to pierwszy raz styszat, a to sa bohaterowie tu, w kraju (o drużynie Górskiego). (Sp)

- Polska to kraj egzotyczny dla Europejczyka (Niemca) z zachodniej części kontynentu:

S. M.: A ja widziałem jeszcze bardziej egzotyczny plakat, mianowicie, przepraszam, dla mnie egzotyczny, yyy ... „Kurs języka polskiego w Krakowie". Ja wiem, że teraz nikt się nie śmieje, ale dla mnie egzotyczne. I iii postanowiłem tam pojechać. I rzeczywiście, chociaż tam wszyscy przyjaciele mówili: ,, Co ty tam chcesz w Azji, zwariowałeś? (Hu)

- Polacy są konserwatywni, wiara katolicka nie pozwala im na przyjmowanie najnowszych tendencji społecznych, burzących dotychczasowy porządek:

S. M.: (...) Ja myślę, że Kraków to jest pruderyjne, katolickie miasto, a co się dzieje? Festiwal współczesnej muzyki feministycznej. Bo ja trochę znatem język włoski. Ja(sic!) po włosku jest tak, zaraz możesz Antonio to potwierdzić, wszystkie kobiety maja na końcu ,a”, Gina Lolo Brigida, Ludwika van Beethovena. Ja myślatem, że ... (Hu)

- znają tylko stereotypy o innych, nie znają jednostek:

K. A.: Polacy nie mają racji, jak mówia, że Anglicy sa flegmatyczni.

M. R.: Naprawdę?

K. A.: Jeżeli chodzi o mnie to na pewno. 
J. B.: To tylko stereotypy, tak?

K. A.: Taak. $(\mathrm{Hu})$

Tutaj dodatkowo w wypowiedzi Kevina Aistona pokazana jest natura stereotypu, zasadzająca się na uogólnieniu oraz posiada odporność na jednostkowe doświadczenia, które najczęściej przeczą generalizacji zawartej w stereotypie.

- Polak-złodziej: stereotyp znany w Europie i utrwalony w dowcipie niemieckim:

S. M.: i yyy jednak sq takie głupie wyjatki, to sa takie rasistowskie dowcipy o Polakach, przepraszam bardzo, ja o... oczywiście nie lubię takich dowcipów, sam je nigdy nie opowiadam, ale jest jeden dobry.

(śmiech gości programu i prowadzącej)

S. M.: Poczekajcie.

J. B.: (półgłosem) Jest świetny.

S. M.: Yyy, diabet pojawia się w Stanach Zjednoczonych i mówi: Jestem z moim matym kubetkiem i zabiorę wam wszystkie pieniadze. Ooo, mówiq Amerykanie, proszę, możesz wszystko mieć, mamy za dużo. Aaa??? Idzie do Rosji. Cześć wam wszystkim, jestem diabetkiem z moim matym kubetkiem i zabiorę wam wszystkie pieniadze. Ooo, mówiq Rosjanie, proszę, możesz nam pomóc szukać, nic nie mamy.

(śmiech widowi)

S. M.: Cholera, mówi diabetek. Leci do Polski i mówi: Cześć wam wszystkim, jestem diabetkiem, a gdzie jest mój maly kubetek?

Choć powielony stereotyp jest tutaj w pełnej odsłonie pokazującej niechęć do Polaków, to jego emocjonalne przewartościowanie w ustach mówiącego w pewnym sensie unieszkodliwia jego negatywny charakter. Efekt humorystyczny, który wysunięty jest tu na pierwszy plan i któremu podporządkowany został stereotyp ten, jak i inne (por. Bogusz 2012: 25), pokazuje, że nawet negatywne wyobrażenia mogą spełniać inne funkcje, niż ich pierwotnie narzucające się właściwości. Można powiedzieć, że jest tutaj - jak i w przeważającej części programów z tego cyklu - toczona swoista gra ze stereotypem, który jest pokazywany, ale jednocześnie kreowany według potrzeb $\mathrm{i}$ intencji programu. 


\section{Wnioski}

Autostereotyp pozytywny przedstawiany jest skromniej przez Polaków biorących udział programie - prowadzącą Monikę Zamachowską oraz zaproszonych do danego odcinka gości programu - szczególnie wówczas, gdy pozytywne treści komunikowane są przez obcokrajowców. Wynika to z zasad tradycyjnej polskiej grzeczności językowej, według obowiązujących zasad jest zasada pomniejszania własnej wartości czy pomniejszania własnych zasług (Marcjanik 2002: 273). Takie zachowanie językowe w prezentacji autostereotypu pozwala na $\mathrm{w}$ miarę równomierne eksponowanie zalet różnych narodowości i sprawia wrażenie równorzędności nacji europejskich, mimo wyraźnych różnic dzielących przedstawicieli krajów obecnych w programie. Również sposób zwracania się do siebie uczestników programu oparty na braku dystansu oraz wręcz familijności (Bogusz 2016: 100) sprzyja łagodzeniu różnic wynikających ze autostereotypu jak i stereotypów przedstawianych w programie.

Stereotyp Polaka w większości pokrywa się z dotychczasowym wizerunkiem utrwalonym w anegdotach, powiedzeniach, tekstach pisanych, ale ulega modyfikacjom, unowocześnieniom (np. imprezowość). W niektórych przypadkach widać, że nawet negatywny stereotyp w nowym kontekście (np. humorystycznym) może zmieniać swoją aksjologię z negatywnej na pozytywną.

Stereotyp można też odczytywać, szczególnie w kontekście programu „Europa da się lubić" jako swoistą (szczątkową) wiedzę wspólną (Szczerbowski 1995: 100) o narodach, która może podlegać i podlega modyfikacji, ale też stanowi materię do pewnego rodzaju gry.

Trwałość i immanentność stereotypów w kulturze dość dobrze określa $T$. Drewniak, pisząc: „Tam bowiem, gdzie upada jakiś stereotyp, na jego miejsce wkracza inny”. I choć ludzkość zupełnie nie pozbędzie się stereotypów, to może je tak modelować, aby bardziej służyły niż przynosiły szkody: „Europa stworzyła nowy ideał współżycia międzynarodowego, który starał się wyrugować wzajemną wrogość i agresję, a nade wszystko mocarstwową, narodową siłę, podporządkowującą sobie innych" (Krzemiński 2015: 36).

\section{Summary}

The article presents an analysis of the stereotype and autostereotype of a Pole seen by other Europeans. In this vision, most of the features seen as stereotypical coincide with the image of the Pole so far. It is possible to notice small modifications, which do not 
fundamentally change the elements of the Pole's stereotype, although they may show it more positively.

Wykaz skrótów:

(Hu) - odcinek programu pt. „Poczucie humoru”, emisja: TVP 2, 16.02.2003 r.

(Sp) - odcinek programu pt. „Sport”, emisja: TVP 2, 18.10.2003 r.

(Wr) - odcinek programu pt. „Europa da się wróżyć”, emisja: TVP 2, 13.12.2003 r.

(Św) - odcinek programu pt. „Europa świąteczna”, emisja: TVP 2, 24.12.2004 r.

(Ba) - odcinek programu pt. „Europa się bawi” TVP2, 11.05.2019 r. („Europa da się lubić - 15 lat później”).

W odcinku pt. „Poczucie humoru” wystąpili: Olivier Boudon (O. B.), Kevin Aiston (K. A.), Steffen Möller (S. M.), Antonio Angotti (A. A.), Paolo Cozza (P. C.), Judit Lencse-Mucha (J. L.).

Gość programu: Joanna Bartel (J. B.).

Prowadzenie: Monika Richardson (M. R.).

W odcinku pt. „Sport” wystąpili: Steffen Möller (S. M.), Elisabeth Duda (E. D.), Kevin Aiston (K. A.), Paolo Cozza (P. C.), Toni Hyyryläinen (T. H.).

Gość programu: Dariusz Michalczewski (D. M.).

Prowadzenie: Monika Richardson (M. R.).

W odcinku pt. „Europa da się wróżyć” wystąpili: Kevin Aiston (K. A.), Witold Casetti (W. C.), Steffen Möller (S. M.), Martina Karlová (M. K.), Theofilos Vafidis (T. V.), Elisabeth Duda (E. D.).

Gość programu: Adam Hanuszkiewicz (A. H.).

Prowadzenie: Monika Richardson (M. R.).

W odcinku pt. „Europa świąteczna” udział wzięli: Martina Karlová (M. K.), Roxana Lichtman (R. L.), Kevin Ainston (K. A.), Paolo Cozza (P. C.), Toni Hyyryläinen (T. H.), Conrado Moreno (C. M.), Steffen Möller (S. M.). 
Goście programu „Europa świąteczna”: Jacek Cygan (J. C.), Jan Dworak (J. D.), Łukasz Golec (G. 1), Paweł Golec (G. 2), Maryla Rodowicz (M. Ro.), Nina Terentiew (N. T.), ks. Władysław Zązel (W. Z.), kard. Józef Glemp (J. G.).

Prowadzenie: Monika Richardson (M. R.).

W odcinku pt. „Europa się bawi” („Europa da się lubić - 15 lat później”) wystąpili:

Kevin Aiston (K. A.), Fausto Corticelli (F. C.), David Gaboriaud (D. G.), Ivana Bílková (I. B.), Lucia Duran (L. D.).

Gość programu: Radek Liszewski (R. L.).

Prowadzenie: Monika Zamachowska (M. Z.).

\section{Literatura}

Bartmiński, J. Stereotypy mieszkaja w języku. Lublin: Wydawnictwo UMSC, 2007.

Bartmiński, J., Paniasiuk, J. Stereotypy językowe In: Bartmiński, J. (ed.) Współczesny język polski. Lublin: Wydawnictwo UMCS, 2014, s. 371-396.

Berting, J., Villian-Gandossi, C. Rola i znaczenie stereotypów narodowych w stosunkach międzynarodowych: podejście interdyscyplinarne In: Walas, T. (ed.) Narody i stereotypy. Kraków: Międzynarodowe Centrum Kultury, 1995, s. 13-27.

Bogusz, B. Humour of the Poles and other Europeans in a television programme "Europe can be liked". Stowo. Studia językoznawcze. 2012 (3), s. 22-32.

Bogusz, B. Formy adresatywne w wybranych odcinkach programu telewizyjnego „Europa da się lubić”. In: Koziara, S., Mączyński, M., Michalik, M., RudnickaFira, E. (eds.) Annales Universitatis Paedagogicae Cracoviensis. Studia Logopedicae V In memoriam Maria Rachwat. Kraków, 2016, s. 94-102.

Drewniak, T. Stereotypy, światoobraz i świat przeżywany. In: Kowalczyk, A., Pacholski, J. (eds.) Stereotype In interkultureller Warhnehmung. Stereotypy w postrzeganiu interkulturowym. Stereotypy z interkulturniho hlediska. Nysa: Oficyna Wydawnicza PWSZ; Wrocław: Oficyna Wydawnicza ATUT Wrocławskie Wydawnictwo Oświatowe, 2005, s. 11-22.

Krzemiński, I. Narody i stereotypy. In: Kusek, R., Purchla, J., Sanetra-Szeliga, J. (eds.) Narody \&Stereotypy 25 lat później. Nowe granice, nowe horyzonty. Kraków: Międzynarodowe Centrum Kultury, 2015, s. 28-37. 
Lippmann, W. Public opinion. New York: Harcourt, Brace and Company, Inc., 1922.

Marcjanik, M. Polska grzeczność językowa. Kielce: Wydawnictwo Akademii Świętokrzyskiej, 2002.

Niewiara, A. Ksztalty polskiej tożsamości. Potoczny dyskurs narodowy w perspektywie etnolingwistycznej (XVI-XX w.). Katowice: Wydawnictwo UŚ, 2009.

Przybysz, P. J. Kilka uwag o stereotypach i tożsamości narodowej na marginesie powieści Henryka Sienkiewicza Ogniem i mieczem. Zeszyty Naukowe Akademii Marynarki Wojennej. 2007 (48/4), s. 97-110.

Quatshoff, U. M. Etnocentryczne przetwarzanie informacji. Ambiwalencja funkcji stereotypów w komunikacji międzykulturowej. In: Anusiewicz, J., Bartmiński, J. (eds.) Język a Kultura (tom 12). Stereotyp jako przedmiot lingwistyki. Teoria, metodologia, analizy empiryczne. Wrocław: Towarzystwo Przyjaciół Polonistyki Wrocławskiej, 1998, s. 11-30.

Szczerbowski, T. Stereotypy etniczne jako element wspólnego świata. Rocznik Naukowo-Dydaktyczny Wyższej Szkoły Pedagogicznej w Krakowie. Prace Rusycystyczne. 1995 (177/9), s. 99-110.

The article is accessible in open access mode under licence CC BY-NC-ND Creative Commons Attribution-NonCommercial-NoDerivatives 4.0 